\title{
Forage characteristics and beef cattle production in perennial pastures of BRS Paiaguás and BRS Piatã in integrated crop livestock system
}

\section{Características da forragem e produção de bovinos de corte em pastos perenes de BRS Paiaguás e BRS Piatã em sistema de integração lavoura pecuária}

\author{
Bianca Midori Souza Sekiya1*; Gelci Carlos Lupatini2; Cristiana Andrighetto2; \\ Franciely de Oliveira Neves ${ }^{1}$; Guilherme Antônio Oliveira Marangoni ${ }^{3}$; \\ Jeferson Mulero3; Rodrigo Medina Lopes ${ }^{4}$
}

\section{Highlights}

The forage demonstrated great potential as perennial pasture in integrated systems.

The grasses presented similar forage characteristics and beef cattle production.

The pasture provided high weight gain per animal and per area.

\begin{abstract}
The integrated crop-livestock system is highlighted in Brazilian agriculture, in which the synergism between the components can increase productivity and animal performance. Forage is one of the most important components because it is the basis of animal feed. Thus, the objective of the study was to evaluate the beef cattle production and pastures characteristics of Urochloa brizantha 'BRS Piatã' and 'BRS Paiaguás', under continuous grazing in an integrated crop livestock system. The experiment was conducted in west of Sao Paulo State, in a randomized complete block design with two treatments and three replicates, from October 2018 to June 2019. The treatments were 3-year-old pastures of BRS Piatã and Paiaguás, in an integrated crop livestock system with perennial pasture and soybean. Nellore steers ( $14 \pm 2$ months old and $244 \pm 13$ $\mathrm{kg}$ initial weight) were used. The grazing method adopted was a continuous stocking with a variable rate to maintain a pasture height of $30 \mathrm{~cm}$. Herbage mass was 5716 and $5480 \mathrm{~kg}$ dry matter ha-1 for Piatã and Paiaguás, respectively. The crude protein, neutral detergent fiber, and acid detergent fiber were similar

1 Master of Animal Science and Technology, Universidade Estadual Paulista "Júlio de Mesquita Filho", UNESP, College of Agricultural and Technological Sciences, Dracena, SP, Brazil. E-mail: bia_souza_sekiya@hotmail.com; franciely. neves@hotmail.com

2 PhD. Prof., UNESP, College of Agricultural and Technological Sciences, Dracena, SP, Brazil. E-mail: gelci.lupatini@ unesp.br; cristiana.andrighetto@unesp.br

${ }^{3}$ Agronomy Undergraduate Students, UNESP, College of Agricultural and Technological Sciences, Dracena, SP, Brazil. E-mail: gui.marangoni@hotmail.com; jeferson15mulero@hotmail.com

${ }^{4}$ Agronomist, Sementes Facholi, Santo Anastácio, SP, Brazil. E-mail: rodrigo.lopes@facholi.com.br

* Author for correspondence
\end{abstract}

Received: Oct. 17, 2020 - Approved: June 08, 2021 
between the two cultivars. The leaf blade mass of BRS Piatã was greater than that of BRS Paiaguás in summer. Animal performance was similar between treatments, with average daily gain of 0.901 and 0.822 kg day-1 and weight gain per area of 888 and $865 \mathrm{~kg} \mathrm{ha}^{-1}$ in Piatã and Paiaguás, respectively. The BRS Piatã and BRS Paiaguás grasses are indicated for use in perennial pastures in integrated crop livestock systems. Key words: Animal performance. Morphological composition. Cultivars. Urochloa brizantha.

\section{Resumo}

A integração lavoura pecuária tem ganhado destaque no cenário da agropecuária brasileira, em que o sinergismo entre os componentes pode melhorar o desempenho e a produtividade animal. Nesse contexto, a forragem é um dos componentes mais importantes. Assim, o objetivo do estudo foi avaliar a produção de bovinos de corte e características de pastagens de Urochloa brizantha 'BRS Piatã' e 'BRS Paiaguás' sob pastejo contínuo em sistema de integração lavoura pecuária. O experimento foi realizado no oeste do estado de São Paulo, com delineamento experimental em blocos ao acaso com três repetições, de outubro de 2018 a junho de 2019. Os tratamentos foram pastagens perenes de três anos de BRS Piatã e Paiaguás, em uma modalidade de integração lavoura pecuária com pastagem perene e soja. Foram utilizados novilhos da raça Nelore, com $14 \pm 2$ meses de idade e peso médio inicial de $244 \pm 13,3 \mathrm{~kg}$. O método de pastejo foi o contínuo com lotação variável, mantendo-se a altura da pastagem em $30 \mathrm{~cm}$. A massa de forragem foi de 5716 e $5480 \mathrm{~kg} \mathrm{MS} \mathrm{ha}^{-1}$ para Piatã e Paiaguás, respectivamente. Os teores de proteína bruta, fibra em detergente neutro e fibra em detergente ácido foram semelhantes entre as duas cultivares. A massa de folhas da BRS Piatã foi maior em relação à BRS Paiaguás no verão. $O$ desempenho animal foi similar entre as cultivares estudadas, sendo o ganho de peso diário 0,901 e 0,822 $\mathrm{kg} \mathrm{dia}^{-1} \mathrm{e}$ o ganho por área 888 e 865 kg ha-1 para Piatã e Paiaguás, respectivamente. O elevado ganho de peso individual e por área obtidos demonstram o grande potencial de uso das duas cultivares na formação de pastagens perenes em sistemas de integração lavoura-pecuária.

Palavras-chave: Desempenho animal. Composição morfológica. Cultivares. Urochloa brizantha.

\section{Introduction}

Given the challenge of meeting the substantial global demand for food in a sustainable manner, more efficient agricultural production systems that increase productivity without negatively affecting the environment are increasingly needed. In Brazil, beef cattle production is based on the use of pastures. However, these systems are still associated with low productivity rates because of the degradation of pastures and incorrect management, leading to production indexes well below their potential.
The intensification of the production system with the use of more efficient models of beef cattle production increases productivity, thereby contributing to more effective and sustainable agriculture. In this context, integrated crop livestock systems (ICLS) have stood out in Brazilian agricultural production in recent decades. These systems achieve synergism between their components, which can improve the chemical, physical, and microbiological characteristics of the soil and increase grain productivity and animal performance in the same area (Cubbage et al., 2012). Additionally, improving pastures with 
an ICLS helps to mitigate greenhouse gas emissions (Wang et al., 2014).

The spatiotemporal characteristics of ICLS pastures vary according to the system and objectives of the property. In the case of a system with perennial pasture and soybean, in which the pasture cycle lasts for more than a year until the crop is regained, an increase in forage production could be noted (Medeiros \& Gomes, 2012), reflecting improvements in animal production and the soil for the subsequent growth of the grain crop.

In these systems, forage is a primary factor for obtaining good results, because it needs to meet production requirements and maintain high productivity during the entire period of use. New forage materials, are still little explored but are an alternative that could contribute more to the consolidation of the modality of the ICLS, including the forage, such as BRS Paiaguás and BRS Piatã, which are evaluated in this work.

The study of these materials will provide information that is lacking in the literature. This information is mainly related to the evaluation of their effectiveness under grazing conditions, with important results regarding animal response and management of perennial pastures, which may help in adapting the forage to the production and system objectives. Therefore, by providing more alternatives for the producer, this information could directly contribute to the improvement of ICLS in Brazil, by intensifying production and diversifying pasture areas undergoing ICLS. Additionally, it could contribute to the advancement of soybean production in edaphoclimatic limited areas.
The objective of this study was to evaluate beef cattle production and characteristics of perennial pastures of the Urochloa brizantha cultivars BRS Piatã and BRS Paiaguás under grazing conditions in an ICLS.

\section{Material and Methods}

The use of animals in this study was certified according to the Ethical Principles in Animal Experimentation issued by the Ethics Committee on the Use of Animals (Protocol No. 27/2018 - ECAU) on August 28, 2018.

The experiment was conducted in an experimental area located in Caiuá City $\left(21^{\circ} 51^{\prime} 28^{\prime \prime} \mathrm{S}, 51^{\circ} 57^{\prime} 37^{\prime \prime} \mathrm{W}\right.$, and $331 \mathrm{~m}$ altitude), west of Sao Paulo state. The soil in the experimental area is Yellow Latosol (Empresa Brasileira de Pesquisa Agropecuária [EMBRAPA], 2013), and the climate of the region is the Aw subtype, according to the Köppen classification. The soil chemical characteristics of the $0-20 \mathrm{~cm}$ layer were as follows: $\mathrm{pH}\left(\mathrm{CaCl}_{2}\right)=5.8$; organic matter $=15 \mathrm{~g}$ $\mathrm{dm}^{-3} ; \mathrm{P}\left(\right.$ resin) $=27 \mathrm{mg} \mathrm{dm}^{-3} ; \mathrm{S}^{-\mathrm{SO}_{4}}=6 \mathrm{mmol}_{\mathrm{c}}$ $\mathrm{dm}^{-3} ; \mathrm{Ca}=39 \mathrm{mmol}_{\mathrm{c}} \mathrm{dm}^{-3} ; \mathrm{Mg}=17 \mathrm{mmol}_{\mathrm{c}} \mathrm{dm}^{-3}$; $\mathrm{K}=2.6 \mathrm{mmol}_{\mathrm{c}} \mathrm{dm}^{-3}$; clay content $=12 \%$; base saturation $=68 \%$.

The climate data related to the experimental period are presented in Figure 1 , which includes the minimum, average, and maximum air temperatures collected from the SistemadeMonitoramentoAgrometeorológico (Agritempo), the meteorological station of Caiuá, São Paulo State (Station TRMM.1208 - Code 9008748), and rainfall data obtained using a conventional rain gauge located in the experimental area and frequently monitored based on the occurrence of rainfall. 


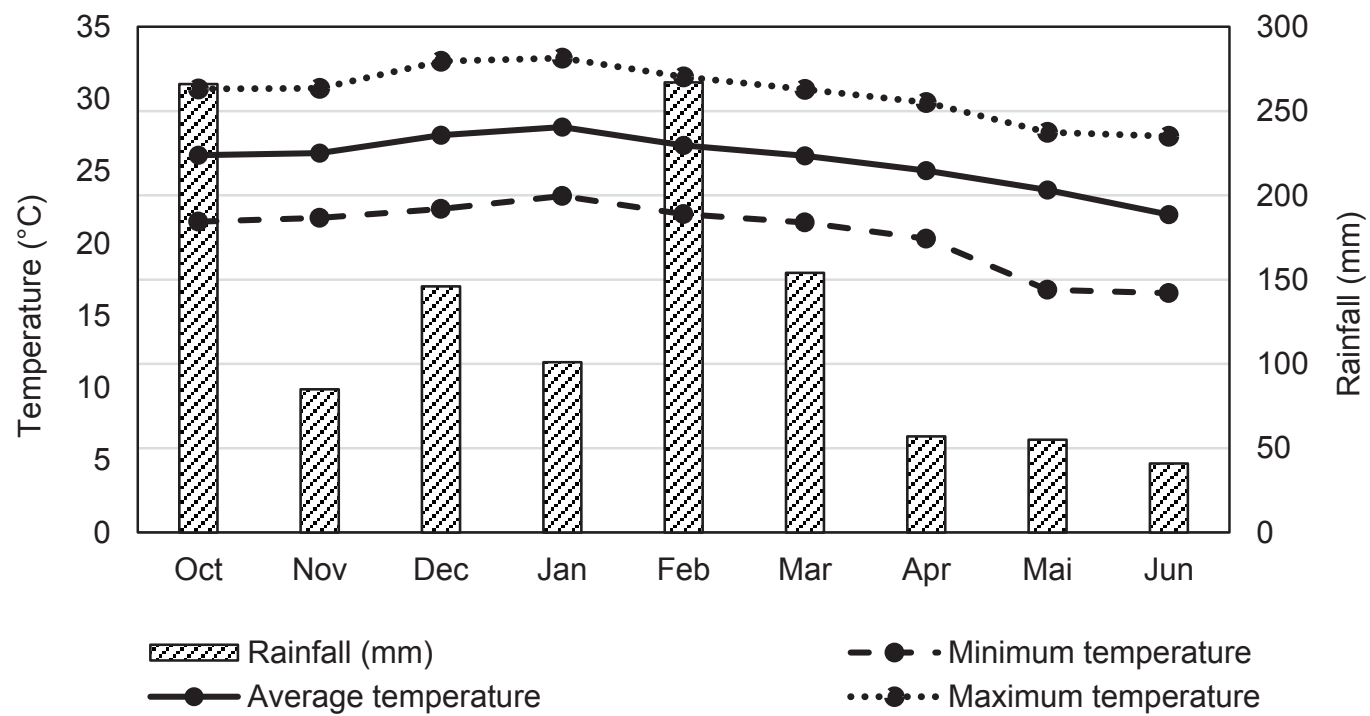

Figure 1. Rainfall and minimum, average and maximum monthly air temperature from October 2018 to June 2019.

Source: Agritempo - Metereological station of Caiuá/SP.

The experiment was designed in randomized blocks (established considering soil attributes) with three replicates (blocks). The treatments were organized in a split-plot over time design, with two cultivars of Urochloa brizantha (BRS Piatã and BRS Paiaguás) considered as plots, and three seasons (spring, summer, and autumn) considered as subplots. The grazing method was continuous stocking with a variable stocking rate (Mott, \& Lucas, 1952) that maintained sward height (SH) management at $30 \mathrm{~cm}$ (Euclides, Montagner, Barbosa, Vale, \& Nantes, 2016). Male Nellore cattle were used, with an average initial live weight of approximately $244 \pm 13 \mathrm{~kg}$ and an average age of $14 \pm 2$ months.

The pastures were established in March 2016. This model of the integrated system consisted of 3 years of pasture (considered as perennial), following one harvest of soybean. The total experimental area was 12 ha, with 2 ha being the average size of each plot (paddock) and the evaluation period was from October 2018 to June 2019 (30 months after establishment).

The implementation of the system began with the sowing of soybean in November 2015. Fertilization provided was $13 \mathrm{~kg} \mathrm{ha}^{-1}$ of $\mathrm{N}, 142 \mathrm{~kg} \mathrm{ha}^{-1}$ of $\mathrm{P}_{2} \mathrm{O}_{5^{\prime}}$ and $74 \mathrm{~kg}$ $\mathrm{ha}^{-1}$ of $\mathrm{K}_{2} \mathrm{O}$. Soybean harvest was conducted in March 2016. Thereafter, $5.0 \mathrm{~kg} \mathrm{ha}^{-1}$ pure viable seeds of cultivars BRS Piatã and BRS Paiaguás (Urochloa brizantha) were sown in rows with 0.4 $\mathrm{m}$ spacing and intercropped with maize (DKB 177) cultivated with $0.9 \mathrm{~m}$ spacing between rows. Fertilization was performed by applying $24 \mathrm{~kg} \mathrm{ha}^{-1}$ of $\mathrm{N}, 84 \mathrm{~kg} \mathrm{ha}^{-1}$ of $\mathrm{P}_{2} \mathrm{O}_{5^{\prime}}$ and $48 \mathrm{~kg}$ $\mathrm{ha}^{-1}$ of $\mathrm{K}_{2} \mathrm{O}$. The maize grains were harvested in July 2016, leaving the formed pastures.

From April to June 2017, grazing standardization was performed using Nellore steers in continuous grazing to maintain a $\mathrm{SH}$ of $30 \mathrm{~cm}$. In November, topsoil fertilization was applied with $127 \mathrm{~kg} \mathrm{ha}^{-1}$ of $\mathrm{N}, 51 \mathrm{~kg} \mathrm{ha}^{-1}$ of 
$\mathrm{P}_{2} \mathrm{O}_{5}$, and $57 \mathrm{~kg} \mathrm{ha}^{-1}$ of $\mathrm{K}_{2} \mathrm{O}$, divided into three applications performed in November 2017, December 2017, and February 2018. From November 2017 to June 2018, continuous grazing with variable stocking rate using Nellore steers was performed, maintaining the $\mathrm{SH}$ at $30 \mathrm{~cm}$. After this period, the area was at rest from the beginning of the experiment. In November 2018, pasture fertilization was again performed, applying $96 \mathrm{~kg} \mathrm{ha}^{-1}$ of $\mathrm{N}$ (divided into two applications conducted in November 2018 and January 2019), $31 \mathrm{~kg} \mathrm{ha}^{-1}$ of $\mathrm{P}_{2} \mathrm{O}_{5}$, and $30 \mathrm{~kg} \mathrm{ha}^{-1}$ of $\mathrm{K}_{2} \mathrm{O}$.

The SH was measured every $14 \mathrm{~d}$, at 90 random points per experimental unit, using a ruler graduated in centimeters. The height at each point was the average canopy height surrounding the ruler (Carnevalli et al., 2006; Euclides et al., 2015).

The herbage mass (HM) evaluation was conducted every $42 \mathrm{~d}$ with nine representative samples from each plot, harvesting all the forage inside a frame measuring $1.0 \times 0.5 \mathrm{~m}$ $\left(0.5 \mathrm{~m}^{2}\right)$, which was then weighed. After each sample was homogenized, a sub-sample weighing approximately 400-500 g was taken which was weighed before and after drying in a forced air circulation oven at $65{ }^{\circ} \mathrm{C}$ until a constant weight was reached to determine the dry matter (DM) content. Based on sample weight, DM content, and sampling area, the herbage mass was expressed as $\mathrm{kg} \mathrm{DM} \mathrm{ha}^{-1}$.

In the morphological composition evaluation of the sample collected to determine the herbage mass (HM), a second sub-sample weighing approximately 400-500 g was collected, which was manually separated into the leaf blade (LB), stem (sheath + stem; SS), and senescent material (SM). Next, the amount of each component was dried in a forced air circulation oven at $65{ }^{\circ} \mathrm{C}$ until it reached a constant weight. Then, the percentage of the components in $\mathrm{HM}$ was determined and converted into $\mathrm{kg} \mathrm{DM} \mathrm{ha}^{-1}$. The leaf:stem ratio (LS) was obtained from the quotient between the LB and SS masses.

For the chemical composition analysis of forage, grazing simulation was performed, simulating the process of reaping the forage by the animals in each experimental plot, according to Johnson (1978). These samples were dried in a forced air circulation oven at $65{ }^{\circ} \mathrm{C}$ until reaching a constant weight and ground in a $1 \mathrm{~mm}$ mesh in a Willey-type mill. The contents of DM, crude protein (CP), and mineral matter (MM) were analyzed according to Association of Official Analytical Chemistry [AOAC] (1995) and neutral detergent fiber (NDF) and acid detergent fiber (FDA) according to Van Soest, Robertson and Lewis (1991).

Six test animals were used per plot, in three replicates, totaling 36 animals kept under continuous stocking, plus the regulator animals (of the same weight, age, and origin as the test animals) for stocking adjustment. The animal adaptation period was $14 \mathrm{~d}$. During the experiment, the animals were treated for clostridiosis, endoparasites, and foot-andmouth disease and regularly monitored for ectoparasite control. The animals received a protein mineral supplementation ad libitum in covered troughs, which was monitored daily to ensure an adequate available amount to allow free consumption of the product by the animals during the entire experimental period. The supplement was Potenfós Rebanho, Potensal ${ }^{\circledR}$, which presented the following composition (guarantee levels per $\mathrm{kg}$ of product): $80-90 \mathrm{~g} \mathrm{Ca}, 30 \mathrm{mg} \mathrm{Co}, 700 \mathrm{mg} \mathrm{Cu}$, $10 \mathrm{mg} \mathrm{Cr}, 10 \mathrm{~g} \mathrm{~S}, 400 \mathrm{mg} \mathrm{F}, 40 \mathrm{~g} \mathrm{P}, 34 \mathrm{mg} \mathrm{I}, 5$ g Mg, 1000 mg Mn, 10 mg Se, 76 g Na, 2000 
mg Zn, 236 g non-protein nitrogen, 250 g CP, and $700 \mathrm{mg}$ sodium salinomycin. The average consumption detected was approximately 52 g for every $100 \mathrm{~kg} \mathrm{BW.}$

The animals were weighed on an electronic digital scale every 42 d after 16 $h$ of fasting. Average daily gain (ADG) was calculated as follows: $A D G=(B W f-B W f) / D$, in which: $\mathrm{BWf}=$ body weight $(\mathrm{kg})$ of test animals in the last weighing of period; $\mathrm{BWi}=$ body weight $(\mathrm{kg})$ of test animals in the initial weighing of period; and $\mathrm{D}=$ number of days in the period. The stocking rate (SR) was obtained by: $\mathrm{SR}=$ TW / A, where TW = total weight $(\mathrm{kg})$ of test and regulator animals grazing in the paddock and $A=$ paddock area (ha). The SR was expressed as an animal unit (AU) corresponding to $450 \mathrm{~kg}$ of live body weight. The weight gain per area (WGA) was calculated as follows: WGA = (ADG $\times N \times D) / A$, where ADG = average daily gain (kg day $^{-1}$ ) of test animals; $N=$ number of test and regulator animals kept in the paddock during the period; $D=$ number of days in the period; and $A=$ paddock area (ha).

Statistical analysis was performed using the Statistical Analysis System software (SAS ${ }^{\circledR}$, University Edition version) (Cody, 2015) at $5 \%$ probability. The model included the random effect of blocks and fixed effects of cultivars, seasons, and their interactions (cultivars $\times$ seasons). Data normality was verified using the Shapiro-Wilk test. Analysis of variance was performed using the "Proc mixed" procedure in SAS. The Akaike information criterion (AIC) was used to identify the best matrix adjustment. The means were fitted to the model using the "Ismeans" statement, and the results are reported as least squares and were separated using the probability difference (pdiff option). To evaluate the main effects of cultivar, season, and simple effects of interactions, the means were compared using Tukey's test at a probability of 0.05 .

\section{Results and Discussion}

The average $\mathrm{SH}$ of the pasture during the experiment was close to the recommended value, being $29.07 \mathrm{~cm}$ for Piatã and 29.78 $\mathrm{cm}$ for Paiaguás (Table 1). This contributed to the forage similarly when expressing the development in forage mass. Among the seasons, spring had the highest $\mathrm{SH}$, followed by summer and autumn. Even with the SR adjustment, the conditions of precipitation and temperature influenced the growth of grasses, and consequently, their heights.

HM did not differ between the BRS Paiaguás and BRS Piatã pastures (Table 1). In the spring and summer, HM was similar but it was greater than in autumn. It was also related to the weather conditions, including higher rainfall and temperatures, which contributed to the growth and development of forage in spring and summer (Figure 1). 
Table 1

Herbage mass and morphological composition of Urochloa brizantha 'BRS Piatã' and 'BRS Paiaguás' in integrated crop livestock system. Caiuá/SP, 2018-2019

\begin{tabular}{|c|c|c|c|c|c|c|}
\hline & $\mathrm{SH}$ & $\mathrm{HM}$ & LB & SS & SM & LS \\
\hline & $\mathrm{cm}$ & ------------. & ------- kg & ha-1 ------- & -----------" & \\
\hline \multicolumn{7}{|l|}{ Cultivars } \\
\hline BRS Piatã & 29.07 & 5715.87 & 1235.78 & 1732.50 & 2887.48 & 0.72 \\
\hline BRS Paiaguás & 29.78 & 5479.81 & 925.38 & 1432.24 & 3177.50 & 0.67 \\
\hline \multicolumn{7}{|l|}{ Seasons } \\
\hline Spring & $35.23 a$ & $5951.98 a$ & 1226.50 & 2133.36a & 2894.92 & $0.58 b$ \\
\hline Summer & $28.75 b$ & $6008.18 a$ & 1168.52 & $1627.44 b$ & 3194.22 & $0.73 a$ \\
\hline Autumn & $24.28 c$ & 4833.37b & 828.72 & $996.30 c$ & 3008.35 & $0.78 a$ \\
\hline SEM & 1.23 & 201.93 & 70.96 & 130.57 & 119.05 & 0.03 \\
\hline \multicolumn{7}{|l|}{ P-value } \\
\hline Cultivar & 0.6562 & 0.5935 & 0.0435 & 0.1727 & 0.2929 & 0.2525 \\
\hline Season & 0.0002 & 0.0239 & 0.0023 & $<0.0001$ & 0.5141 & 0.0028 \\
\hline Interaction & 0.4307 & 0.6159 & 0.0311 & 0.3719 & 0.7101 & 0.2496 \\
\hline
\end{tabular}

a.b,c Means with different superscripts in the columns differ significantly at $\mathrm{P}<0.05$.

$\mathrm{SH}$, Sward height; HM, herbage mass; LB, leaf blade mass; SS, stems + sheaths mass; SM, senescent material mass; LS, leaf-stem ratio; DM, dry matter; SEM, standard error of the mean.

Euclides et al. (2016) also observed similar HM between Piatã and Paiaguás. They differed between the time of the year, with $3075 \mathrm{~kg} \mathrm{DM} \mathrm{ha}^{-1}$ in the rainy season and 2660 $\mathrm{kg} \mathrm{DM} \mathrm{ha}^{-1}$ in the dry season. The available HM differed between the trials and were associated with the previous experiments, rain amount, and distribution because the same fertilization was used. Salton et al. (2013) evaluated the livestock performance in an ICLS with a 2 year pasture stage and found better performance of livestock was caused by a higher quality and quantity of forage available, compared to traditional pastures.

In terms of morphological composition, the SS and SM masses did not differ between Piatã and Paiaguás. The same was observed by Euclides et al. (2016). The greatest SS was observed in spring, followed by summer and autumn, respectively. Although HM was similar between spring and summer, SS response was associated with pasture management before the experiment. There was no grazing in winter, promoting greater stem accumulation that represented $36 \%$ of the $\mathrm{HM}$ in the spring versus $27 \%$ in the summer, and contributed to the greater SM during the spring.

The LS did not differ between Piatã and Paiaguás, and was lower in the spring because of the higher mass of stems in this season. The LS ratio is important to animal nutrition and pasture management because higher leaf or stem mass in the HM changes the composition of consumed forage (Kroth, Silva, Silva, Koetz, \& Schlichting, 2015). Even with the lower LS ratio in the spring, which could limit food capture by the animals (Euclides, Montagner, Barbosa, \& Nantes, 2014), the amount of 
leaves, which is associated with greater ease of forage collection and voluntary intake (Montagner et al., 2011), did not negatively affect animal performance.

Aguilar et al. (2019) evaluated the performance of Nellore heifers on $U$. brizantha 'Marandu' pasture fertilized with nitrogen and reported a higher ADG caused by the positive effects of nitrogen fertilization, which provided a greater availability of leaf blades, resulting in intake of forage with better nutritive value. As the fertilization effect was reduced, the authors detected a lower availability of leaf blades, which led to a reduction in grazing selection and no positive effect on animal performance. Lima et al. (2019) evaluated $U$. decumbens in the silvopastoral system and found that higher leaf blade amounts may have positively contributed to animal nutrition, despite lower forage mass, resulting in small differences in weight gain. Nantes et al. (2013) analyzed the structural characteristics of Piatã grass and found that the leaf blade mass was slightly lower than that in the present study (1090, 1085, and 770 kg DM ha-1 in spring, summer, and autumn, respectively), which was associated with a lower CP content (10.7\%), resulting in a GMD of $0.650 \mathrm{~kg}$ day $^{-1}$.

A significant interaction between cultivar and season was observed for LB mass. Piatã presented a higher LB mass than Paiaguás in summer (Table 2). In spring and autumn, the LB masses were similar. As reported by Nantes et al. (2013), Piatã presents higher leaf accumulation in summer, and is associated with bigger leaves compared to Paiaguás (Euclides et al., 2016). Thus, this contributed to the higher LB mass in this season.

\section{Table 2}

Leaf blades mass (kg DM ha-1) of Urochloa brizantha 'BRS Piatã' and 'BRS Paiaguás' in integrated crop livestock system. Caiuá/SP, 2018-2019

\begin{tabular}{cccc} 
& Spring & Summer & Autumn \\
\hline BRS Piatã & $1239.91^{\mathrm{abA}}$ & $1471.87^{\mathrm{aA}}$ & $995.55^{\mathrm{bA}}$ \\
\hline BRS Paiaguás & $1213.10^{\mathrm{aA}}$ & $901.16^{\mathrm{abB}}$ & $661.89^{\mathrm{bA}}$
\end{tabular}

$a, b, c$ Means with different lowercase superscripts in rows or different uppercase in columns differ significantly at $P<0.05$.

No difference was observed in the LB mass in Paiaguás between spring and summer, or between summer and autumn. It only differed between the spring and autumn. For Piatã grass, the LB mass was similar between spring and summer and between spring and autumn. It only differed between summer and autumn. This observation suggests that the greatest potential for LB production in Piatã is at times of optimum water and temperature conditions, whereas Paiaguás has a more stable LB production potential across the seasons. The results require addition study, including that of winter weather conditions, morphogenic characteristics, structure, and herbage accumulation in the pasture, to provide more detailed answers regarding forage behavior over the year.

No differences in $\mathrm{CP}$ between Piatã and Paiaguás were found. In the seasons, higher levels were observed in the summer, followed by spring and autumn (Table 3 ). The 
higher CP in the summer was mainly caused by weather conditions and the availability of LB, as well as the fertilization applied during this period. Fertilization causes an increase in the nitrogen compounds from the fertilizer and a higher mineralization rate and nutrient cycling because of the soil moisture conditions (Marcelo, Corá, \& Fernandes, 2012), thereby resulting in higher CP content. Considering this, the lower availability of LB, lower soil moisture, lower temperature, and the fertilization consumed by the forage over time explain the lower CP in the autumn.

There was no difference in NDF between the forage cultivars. The NDF in autumn did not differ from summer, and summer did not differ from spring, but NDF differed between autumn and spring. According to the advance of the phenological stage of the plants, there was an increase in the NDF content because of the decrease in photoperiod and temperature, as well as the accumulation of senescent material from the forage concentration during this period (Fioreli et al., 2018). The unfavorable climatic factors in the autumn impaired vegetative growth, which contributed to greater lignification of the cell wall of the leaves and stems in this period, leading to higher NDF. There was no observed difference in ADF between cultivars or between seasons.

\section{Table 3}

Chemical composition (g kg DM'-1) of Urochloa brizantha 'BRS Piatã' and 'BRS Paiaguás' in integrated crop livestock system. Caiuá/SP, 2018-2019

\begin{tabular}{|c|c|c|c|c|}
\hline & $\mathrm{CP}$ & NDF & ADF & $\mathrm{MM}$ \\
\hline \multicolumn{5}{|c|}{ Cultivars } \\
\hline BRS Piatã & 12.77 & 59.69 & 29.10 & 7.36 \\
\hline BRS Paiaguás & 14.60 & 59.58 & 29.47 & 7.40 \\
\hline \multicolumn{5}{|c|}{ Seasons } \\
\hline Spring & $13.72^{\mathrm{b}}$ & $58.24^{b}$ & 28.38 & $8.10^{\mathrm{a}}$ \\
\hline Summer & $15.24^{\mathrm{a}}$ & $59.84^{\mathrm{ab}}$ & 30.12 & $7.80^{\mathrm{a}}$ \\
\hline Autumn & $12.09^{c}$ & $60.83^{a}$ & 29.36 & $6.23^{b}$ \\
\hline SEM & 0.47 & 0.56 & 0.39 & 0.25 \\
\hline \multicolumn{5}{|c|}{ P-value } \\
\hline Cultivar & 0.0730 & 0.8910 & 0.5499 & 0.9286 \\
\hline Season & 0.0039 & 0.0460 & 0.0718 & 0.0002 \\
\hline Interaction & 0.5536 & 0.1929 & 0.9815 & 0.2135 \\
\hline
\end{tabular}

a,b,c Means with different superscripts in the columns differ significantly at $\mathrm{P}<0.05$.

$\mathrm{CP}$, crude protein; NDF, neutral detergent fiber; ADF, acid detergent fiber; MM, mineral matter; SEM, standard error of the mean.

MM was similar between the cultivars. Differences were observed among the seasons, with spring and summer being higher than in autumn. This could be explained by the higher availability of minerals through fertilization because it increases the mineral 
content of plants; however, the difference between forage species was not significant (Castagnara et al., 2011; Gomide, 1976). Additionally, lower soil moisture caused by lower rainfall contributed to the reduction of nutrient transportation into the plant, resulting in lower MM in autumn (Rodrigues et al., 2015).

Regarding animal performance, ADG was similar between Piatã and Paiaguás cultivars (Table 4). For seasons, ADG was similar between spring and summer and lower in autumn. Animal performance is related to the availability and quality of forage, which is associated with $\mathrm{CP}$, mineral and fiber content, and digestibility (F. F. Silva et al., 2009). According to F. F. Silva et al. (2009), at least 4500 and $1200 \mathrm{~kg} \mathrm{ha}^{-1}$ of total DM and green DM, respectively, a supply of $10-12 \%$ of the BW of forage DM is required to guarantee selectivity and satisfactory individual gains without compromising the gain per area.
In addition, 7\% CP content of the diet is the minimum such that there is no damage to the microorganisms of the rumen, whereas levels above $60 \%$ NDF compromise the consumption of forage, and above $40 \%$ FDA negatively affects their digestibility, interfering with the weight gain (Van Soest, 1994). Valadares et al. (2016) estimated the

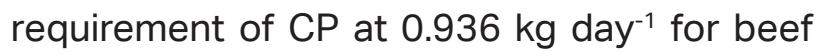
cattle of different sex classes raised on pasture, $350 \mathrm{~kg} \mathrm{BW}$, consuming $7.65 \mathrm{~kg}$ DM day $^{-1}$ to reach an ADG of 1.0 day $^{-1}$. Considering the CP content of this study (Table 3), the CP supply would correspond to 0.976 and 1116.9 $\mathrm{kg}$ day $^{-1}$ for Piatã and Paiaguás, respectively, meeting the requirements of this nutrient for the desired ADG. In the present study, good pasture conditions over the experiment, which met the requirements of a quality forage, contributed to the responses in animal performance.

\section{Table 4}

Animal performance and stocking rate of Nelore steers in pastures of Urochloa brizantha 'BRS Piatã' and 'BRS Paiaguás' in integrated crop livestock system. Caiuá/SP, 2018-2019

\begin{tabular}{|c|c|c|c|}
\hline & ADG (kg day $\left.{ }^{-1}\right)$ & SR $\left(A U h^{-1}\right)$ & WGA (kg ha-1) \\
\hline \multicolumn{4}{|c|}{ Cultivars } \\
\hline BRS Piatã & 0.901 & 3.10 & 888 \\
\hline BRS Paiaguás & 0.822 & 3.25 & 865 \\
\hline \multicolumn{4}{|c|}{ Seasons } \\
\hline Spring & $0.938 a$ & $3.68 a$ & $300 b$ \\
\hline Summer & $0.856 a$ & $3.41 a$ & $380 a$ \\
\hline Autumn & $0.791 b$ & $2.44 b$ & $197 c$ \\
\hline SEM & 0.023 & 0.14 & 19 \\
\hline \multicolumn{4}{|c|}{ P-value } \\
\hline Cultivar & 0.1013 & 0.4132 & 0.6809 \\
\hline Season & 0.0072 & $<0.0001$ & $<0.0001$ \\
\hline Interaction & 0.8433 & 0.4559 & 0.5173 \\
\hline
\end{tabular}

a,b,c Means with different superscripts in the columns differ significantly at $P<0.05$.

ADG, average daily gain; WGA, weight gain per area; SR, stocking rate; $A U$, animal unit corresponding to $450 \mathrm{~kg}$ of live weight; SEM = standard error of the mean. Spring = 10/31/2018 to 12/20/2018; Summer = 12/21/2018 to 03/14/2019; Autumn = 03/15/2019 to 06/06/2019. 
In spring and summer, the ADG was similar, despite the same HM with lower CP content in the spring, possibly complemented by the supplement, balancing the ADG between these seasons. The lowest HM with the lowest CP and highest NDF resulted in the lowest ADG in autumn.

Euclides et al. (2016) evaluated Piatã and Paiaguás under grazing in ICLS for 2 years, and observed an ADG of $0.640 \mathrm{~kg} \mathrm{day}^{-1}$ for Piatã and $0.690 \mathrm{~kg} \mathrm{day}^{-1}$ for Paiaguás during the rainfall period from October to April, with no difference between cultivars. Montagner et al. (2018) evaluated the same cultivars and obtained ADG values of $0.640,0.610$, and $0.600 \mathrm{~kg} \mathrm{day}^{-1}$ in spring, summer, and autumn, respectively, which did not differ. The authors found a lower ADG compared to the present study, because of the lower HM (2310 and $2690 \mathrm{~kg} \mathrm{DM} \mathrm{ha}^{-1}$ for Paiaguás and Piatã, respectively), with NDF levels close to $70 \%$.

SR was similar between the studied forages (Table 4). Autumn presented lower SR than spring and summer, which did not differ between them. The SR behavior followed the same trend as $\mathrm{HM}$, considering that the capacity of pasture support is related to the availability of forage to the animals, which was reduced according to the reduction in precipitation and temperatures in the autumn (Figure 1).

Similar results were found by Montagner et al. (2018), in which Piatã and Paiaguás presented an average SR of $4 \mathrm{AU} \mathrm{ha}^{-1}$ from spring to autumn, without differences between seasons. However, these authors confirmed that the differences in SR could achieve 2.5 AU ha-1 more in summer than in spring and autumn, according to the variation in the availability and nutritional value of the forage that lead to an SR reduction in unfavorable seasons to supply forage to the animals and to guarantee remaining leaf area for regrowth.

The WGA was similar between Piatã and Paiaguás (Table 4). Among the seasons, the WGA was greater in summer, followed by spring and autumn. The WGA is determined according to the individual gain multiplied by the stocking supported by the pasture; therefore, ADG associated with SR determines the WGA during each grazing cycle (Montagner et al., 2018). Thus, with similar ADG and SR, the WGA also showed did not differ between the forage types.

However, even when presenting similar $A D G$ and $S R$ in spring and summer, WGA was differed between these seasons. This is explained by the difference in the number of grazing days, which was $51 \mathrm{~d}$ in spring and 84 d in summer. Thus, spring had 33 fewer grazing days and presented $102.1 \mathrm{~kg} \mathrm{ha}^{-1}$ more (52\%) in relation to autumn, because of higher ADG and SR. The lower WGA found in autumn was caused by the effect of lower AGD and SR during this season.

In this study, ADG and WGA demonstrated the substantial potential of the evaluated forage as perennial pasture grasses in the ICLS. It is worth highlighting the importance of managing the pasture correctly, respecting the limits of grasses to preserve animal feed, based on planning and monitoring pasture conditions in all areas of the property throughout the year, ensuring good yield. 


\section{Conclusions}

The cultivars presented similar characteristics, with better forage quality in spring and summer, resulting in higher animal performance. Beef cattle production was similar to that of the cultivars, which was managed well, resulting in high animal productivity in the ICLS. Therefore, BRS Piatã and BRS Paiaguás grasses are indicated for use as perennial pastures in ICLS.

\section{Acknowledgments}

We thank Grupo Facholi for providing the area and financial support to develop the experiment. This study was financed in part by the Coordenação de Aperfeiçoamento de Pessoal de Nível Superior - Brasil (CAPES) Finance Code 001.

\section{References}

Aguilar, P. B., Teixeira, F. A., Silva, F. F., Pires, A. J. V., Fries, D. D., Nascimento, P. V. N., Soares, A. N. M. (2019). Performance of Nellore heifers on deferred Urochloa brizantha pasture fertilized with Nitrogen. International Journal of Development Research, 9(10), 30924-30928. Recovered from https://www.journalijdr. com/performance-nellore-heifersdeferred-urochloa-brizantha-pasturefertilized-nitrogen

Association of Official Analytical Chemistry (1995). Official methods of 4 analysis (15nd ed.). Washington, DC: AOAC.

Carnevalli, R. A., Silva, S. C., Bueno, A. A. O., Uebele, M. C., Hodgson, J., Silva, G. N., \&
Morais, J. P. G. (2006). Herbage production and grazing glosses in Panicum maximum cv. Mombaça under four grazing managements. Tropical Grasslands, 40(3), 165-176. Recuperado de https://www. tropicalgrasslands. info/public/journals/4/ Historic/Tropical\%20Grasslands\%20 Journal\%20archive/Abstracts/Vol_40 _2006/Abs_40_03_2006_pp165_176. htm

Castagnara, D. D., Mesquita, E. E., Neres, M. A., Oliveira, P. S. R., Deminicis, B. B., \& Bamberg, R. (2011). Valor nutricional e características estruturais de gramíneas tropicais sob adubação nitrogenada. Archivos de Zootecnia, 60(232), 931-942. doi: 10.4321/S000405922011000400010

Cody, R. (2015). An introduction to SAS university edition. Cary, NC: SAS Institute INC.

Cubbage, F., Balmelli, G., Bussoni, A., Noellemeyer, E., Pachas, A. N., Fassola, H.,... Hubbard, W. (2012). Comparing silvopastoral systems and prospects in eight regions of the world. Agroforestry Systems, 86(3), 303-314. doi: 10.1007/ s10457-012-9482-z

Empresa Brasileira de Pesquisa Agropecuária (2013). Sistema brasileiro de classificação de solos (3a ed.). Rio de Janeiro: Centro Nacional de Pesquisa de Solos.

Euclides, V. P. B., Lopes, F. C., Nascimento, D., Jr., Silva, S. C., Difante, G. S., \& Barbosa, R. A. (2015) Steer performance on Panicum maximum (cv. Mombaça) pastures under two grazing intensities. Animal Production Science, 56(11), 1849-1856. doi: 10.1071/ AN14721 
Euclides, V.P. B., Montagner, D. B., Barbosa, R. A., \& Nantes, N. N. (2014). Manejo do pastejo de cultivares de Brachiaria brizantha (Hochst) Stapf e de Panicum maximum Jacq. Revista Ceres, 61(7), 808-818. doi: 10.1590/0034-737x201461000006

Euclides, V.P.B., Montagner, D. B., Barbosa, R. A., Valle, C. B. do, \& Nantes, N. N. (2016). Animal performance and sward characteristics of two cultivars of Brachiaria brizantha (BRS Paiaguás and BRS Piatã). Revista Brasileira de Zootecnia, 5(3), 85-92. doi: 10.1590/S1806-92902016000300001

Fioreli, A. B., Ziech, M. F., Fluck, A. C., Gerei, J. C., Col, D., Berns, L.,... Costa, O. A. D. (2018). Valor nutritivo de gramíneas do gênero Cynodon consorciadas com amendoim forrageiro. Arquivo Brasileiro de Medicina Veterinária e Zootecnia, 70(6), 1970-1978. doi: 10.1590/1678-4162-10048

Gomide, J. A. (1976). Composição mineral de gramíneas e leguminosas forrageiras tropicais. Anais do Simpósio LatinoAmericano sobre Pesquisa em Nutrição Mineral de Ruminantes em Pastagens, Belo Horizonte, MG, Brasil.

Johnson, A. D. (1978). Sample preparation and chemical analysis of vegetation. In $\mathrm{L}$. $\mathrm{t}^{\prime}$ Mannetje (Ed.), Measurement of grassland vegetation and animal production (pp. 96-102). Aberustwyth: Commonwealth Agricultural Bureaux.

Kroth, B. E., Silva, E. M. B., Silva, T. J. A. da, Koetz, M., \& Schlichting, A. F. (2015). Cultivares de Brachiaria brizantha sob diferentes disponibilidades hídricas em Neossolo Flúvico. Revista Brasileira de Engenharia Agrícola e Ambiental, 19(5), 464-469. doi: 10.1590/1807-1929/agri ambi.v19n5p464-469
Lima, M. A., Paciullo, D. S. C., Morenz, J. J. F., Gomide, C. A. M., Rodrigues, R. A. R., \& Chizzotti, F. H. M. (2019). Productivity and nutritive value of Brachiaria decumbens and performance of dairy heifers in a long-term silvopastoral system. Grass and Forage Science, 74(1), 160-170. doi: $10.1111 /$ gfs. 12395

Marcelo, A. V., Corá, J. E., \& Fernandes, C. (2012). Sequências de culturas em sistema de semeadura direta. II - Decomposição e liberação de nutrientes na entressafra. Revista Brasileira de Ciência do Solo, 36(5), 1568-1582. doi: 10.1590/S0100-06 832012000500021

Medeiros, S. R. de, \& Gomes, R. da C. (2012). Suplementação de bovinos de corte na integração lavoura-pecuária-floresta. In D. J. Bungenstab (Ed.). Sistemas de integração lavoura-pecuária-floresta: a produção sustentável (2a ed., pp. 155175). Brasília, DF: EMBRAPA.

Montagner, D. B., Araújo, A. R., Euclides, V. P. B., Macedo, M. C. M., Zimmer, A. H., \& Andrade, R. A. S. (2018). Potencial produtivo dos capins BRS Piatã e BRS Paiaguás em sistema de integração lavoura-pecuária. Campo Grande, MS: EMBRAPA Gado de Corte. Recuperado de https://www.embrapa.br/ busca-depublicacoes/-/publicacao/1093168/ potencial-produtivo-dos-capins-brspiata-e-brs-paiaguas-em-sistema-deintegracao-lavoura-pecuaria

Montagner, D. B., Rocha, M. G. da, Genro, T. C. M., Bremm, C., Santos, D. T. dos, Roman, J., \& Roso, D. (2011). Ingestão de matéria seca por novilhas de corte em pastagem de milheto. Ciência Rural, 41(4), 686-691. doi: 10.1590/S0103-84782011000400023 
Mott, G. O., \& Lucas, H. L. (1952). The design, conduct, and interpretation of grazing trials on cultivated and improved pastures. Proceedings of the International Grassland Congress, State College, Pennsylvania, USA.

Nantes, N. N., Euclides, V. P. B., Montagner, D. B., Lempp, B., Barbosa, R. A., \& Gois, P. O. (2013). Desempenho animal e características de pastos de capim-piatã submetidos a diferentes intensidades de pastejo. Pesquisa Agropecuária Brasileira, 48(1), 114-121. doi: 10.1590/S0100-204X 2013000100015

Rodrigues, C. T., Jr., Carneiro, M. S. de S., Magalhaes, J. A., Pereira, E. S., Rodrigues, B. H. N., Costa, N. de L., Castro, K. N. de C. (2015). Produção e composição bromatológica do capimMarandu em diferentes épocas de diferimento e utilização. Semina: Ciências Agrárias, 36(3), 2141-2154. doi: 10.54 33/1679-0359.2015v36n3Supl1p2141

Salton, J. C., Kichel, A. N., Arantes, M., Kruker, J. M., Zimmer, A. H., Mercante, F. M., \& Almeida, R. G. de. (2013). Sistema São Mateus: sistema de integração lavourapecuária para a região do Bolsão SulMato-Grossense. Dourados: EMBRAPA Agropecuária Oeste. Recuperado de https://www.embrapa.br/busca-depublicacoes/-/publicacao/960712/ sistema-sao-mateus---sistema-deintegracao-lavoura-pecuaria-para-aregiao-do-bolsao-sul-mato-grossense
Silva, F. F., Sá, J. F., Schio, A. R., Ítavo, L. C. V., Silva, R. R., \& Mateus, R. G. (2009). Suplementação a pasto: disponibilidade e qualidade $x$ níveis de suplementação $\mathrm{x}$ desempenho. Revista Brasileira de Zootecnia, 38(1), 371-389. doi: 10.1590/ S1516-35982009001300037

Valadares, S. C., Fo., Costa e Silva, L. F., Gionbelli, M. P., Rotta, P. P., Marcondes, M. I., Chizzotti, M. L., \& Prados, L.F. (2016). Exigências nutricionais de zebuínos puros e cruzados BR-CORTE. (3a ed.). Viçosa, MG: UFV, DZO.

Van Soest, P. J. (1994). Nutritional ecology of the ruminant (2nd ed.). New York: Cornell University.

Van Soest, P. J., Robertson, J. B., \& Lewis, B. A. (1991). Methods for dietary fiber, neutral detergent fiber, and no starch polysaccharides in relation to animal nutrition. Journal of Dairy Science, 74(10), 3583-3597. doi: 10.3168/jds.S0022-0302 (91)78551-2

Wang, C., Han, G., Wang, S., Zhai, X., Brown, J., Havstad, K. M.,... Li, Z. (2014). Sound management may sequester methane in grazed rangeland ecossystems. Scientific Reports, 4(4444), 1-5. doi: 10.1038/srep 04444 